\title{
Corrosion Resistance Measurements of Amorphous Ni40Ti40Nb20 Bipolar Plate Material for Polymer Electrolyte Membrane Fuel Cells
}

\author{
Gyorgy Thalmaier $^{1 \mathrm{a}}$, Ioan Vida-Simiti ${ }^{1 \mathrm{~b}}$, Horatiu Vermesan $^{1 \mathrm{c}}$, \\ Cosmin Codrean $^{2 \mathrm{~d}}$, Mihail Chira ${ }^{1 \mathrm{e}}$
}

\author{
${ }^{1}$ Technical University of Cluj-Napoca, 103-105 Muncii Ave., 400641 Cluj - Napoca, Romania \\ ${ }^{2}$ Politehnica University of Timisoara, 1 Mihai Viteazu Ave., 300222 Timisoara, Romania \\ a'Gyorgy.Thalmaier@sim.utcluj.ro (corresponding author), ${ }^{b}$ Vida.Simiti@stm.utcluj.ro, \\ cHoratiu.Vermesan@ipm.utcluj.ro, ${ }^{\mathrm{d}}$ CCodrean@gmail.com, ${ }^{\mathrm{e}}$ mihai2706@yahoo.com.
}

Keywords: metallic glass, bipolar plate, polymer electrolyte fuel cell.

\begin{abstract}
Metallic bipolar plates have the advantages of better manufacturability, higher strength over graphite bipolar plates. The higher strength and toughness of the metallic materials permits the reduction of the width of the bipolar plate so, the volume and mass of the fuel cell can also be reduced. In this paper we are investigating the use of Ni-based amorphous material as a bipolar plate for polymer electrolyte membrane fuel cell (PEMFC). The major requirements of the metallic bipolar plate material are low weight, high corrosion and low contact resistance. The corrosion property of the present alloy has been investigated under conditions that simulate the fuel cell environment. Hydrogen gas and air were bubbled into a $1 \mathrm{~N} \mathrm{H}_{2} \mathrm{SO}_{4}$ solution at $70{ }^{\circ} \mathrm{C}$, throughout the experiment to simulate the respective anodic and cathodic PEMFC environment. The Ni-base amorphous alloys displayed higher corrosion resistance than stainless steel.
\end{abstract}

\section{Introduction}

Polymer electrolyte membrane fuel cells (PEMFCs) are energy converters that electrochemically convert oxygen and hydrogen in water, electricity and heat. The operating temperatures are reduced $\left(50-100{ }^{\circ} \mathrm{C}\right)$ and the obtained voltage is small $(\sim 0.7 \mathrm{~V})$. In order to produce a useful voltage a number of cells (depending of the application) have to be connected in series. This can be done using bipolar plates. These plates connect the one cells anode to the cathode of the next cell. The main roles of these plates are to conduct electricity from cell to cell, to separate the hydrogen and oxygen gas flow, and to distribute the gases to the membrane $[1,2]$. Since these plates give $60-80 \%$ of the stack weight, $50 \%$ of the stack volume and $35-45 \%$ of the stack cost [3] using cheaper, lighter and stronger materials significant improvements in the fuel cells could be achieved.

The materials used in manufacturing the bipolar plates must possess a strict combination of proprieties: low resistivity, high thermal conductivity, corrosion resistance, good mechanical properties, low hydrogen permeability, low-cost and weight.

Bipolar plates are conventionally made of graphite; however it cannot be used to produce thin bipolar plates because of its brittleness. In order to have light and more compact fuel cell stacks which are important especially for mobile applications extremely thin $(<1 \mathrm{~mm})$ bipolar plates are needed. Graphite composite materials with polymer binders $[4,5]$ and carbon - carbon composites [6] are more suited to achieve the desired properties and to improve manufacturing technologies for bipolar plates, together with the flow fields and cooling channels [7].

A significant part of the literature deals with the study of bipolar plates made from metals such as stainless steel, titanium or aluminium alloys. Since none of those have the required corrosion resistance different coatings were subjected to improve their behaviour.

Stainless steels were employed in the early stages of developing bipolar plates $[8,9]$. The highly corrosion-resistant stainless steel $316 \mathrm{~L}$ is recognized as the standard material for comparison. Many different types of metallic bipolar plates have been developed based on stainless steels or other alloys with polymer coatings [10], nitride coatings [11-14], and $\mathrm{SnO}_{2}$ coatings [15, 16] carbon and gold coatings [17]. Furthermore, clad materials have also been reported [18]. 
A different class of metallic alloys, the metallic glasses, could be considered as promising candidates. As compared with crystalline alloys, the compositions of metallic glasses are not restricted by the solubility limits, which allow the alloying of strong passivating elements within a wide composition range [19]. Since these alloys natively presents excellent corrosion resistance and high metallic strength due to their structural and chemical homogeneity, there is no grain boundaries or other defects. In addition to the composition and amorphous nature of metallic glasses, free volume (FV), as a microstructure feature for the metastable amorphous structure of metallic glasses, may influence their electrochemical properties. Furthermore, metallic glasses can show viscous flow deformation in a supercooled liquid state, which can simplify the manufacturing process.

A number of nickel based amorphous alloys made of cheap, common metals were proposed to be used as bipolar plates also [20]. The potential of $\mathrm{Ni}-\mathrm{Nb}-\mathrm{Ti}-\mathrm{Zr}$ metallic glasses for use in bipolar plates has previously been studied by Inoue et al. [21]. $\mathrm{Ni}-\mathrm{Nb}-\mathrm{Ti}-\mathrm{Zr}$ metallic glasses have wide supercooled liquid regions of more than $60 \mathrm{~K}$. The optimal composition was found to be Ni60Nb15Ti15Zr10 (at. \%). Yoshioka et al. reported that Ni-Cr-P-B quaternary glassy alloys possess excellent corrosion resistance [22]. The glassy alloy of composition Ni65Cr15P16B4 from the same family can be melt-spun in air without any degradation in its properties and that it had a supercooled liquid region of $43 \mathrm{~K}$ [23].

This paper presents our results on the preliminary evaluation of the amorphous Ni40Ti40Nb20 (at. $\%$ ) alloy as material for bipolar plates in polymer electrolyte fuel cell stacks.

\section{Experimental}

The master alloy (Ni40Ti40Nb20 percentages in at. \%) was prepared by arc melting using high purity metals in a Ti-gettered argon atmosphere. The alloys were melted several times in order to improve homogeneity. The alloy ingot was induction-melted under a high-purity argon atmosphere in a quartz crucible and injected through a nozzle onto a rotating $\mathrm{Cu}$ wheel to produce amorphous tapes. The obtained tapes were $3 \mathrm{~mm}$ wide and approximately $40 \mu \mathrm{m}$ thick.

The amorphous nature of the ribbons was investigated by X-ray diffraction. Thermal stability of the specimens was examined by differential scanning calorimetry (DSC) at the heating rate of 40 $\mathrm{K} / \mathrm{min}$.

The corrosion behaviour of the ribbons was evaluated by electrochemical methods. Potentiodynamic testing was used to analyze the corrosion characteristics of the amorphous samples. The experiments were carried out in a corrosion cell composed of a three-electrode arrangement a $1 \mathrm{~N} \mathrm{H}_{2} \mathrm{SO}_{4}$ solution at $70{ }^{\circ} \mathrm{C}$ bubbled with air and $\mathrm{H}_{2}$. The specimen served as the working electrode, a platinum rod as counter electrode and a saturated $\mathrm{Ag} / \mathrm{AgCl}$ electrode as reference electrode. The undesired areas the ribbons were sealed to prevent contact with the electrolyte. In order to observe any surface topography changes attributed to corrosion, the samples were examined using scanning electron microscopy.

Optical tensiometry was used to measure the water contact angle. The basis for optical tensiometry is the analysis of the shape of a small water drop placed on the sample. The contact angle is determined by image analysis on the captured image.

Interfacial contact resistance (ICR) was approximated by the techniques developed by Davies [7] and Wang [24]. As current collectors gold plated copper plates are used and the gas diffusion layer was simulated by carbon paper. During the measurement the test specimen is covered on both sides by carbon paper and these are sandwiched between the current collectors.

\section{Results and Discussions}

\section{Structure}

Fig. 1. shows the XRD pattern of the as-quenched Ni40Ti40Nb20 ribbons. Only a main halo peak is present without reflections to suggest crystalline phases, indicating the formation of a glassy phase in these samples. 


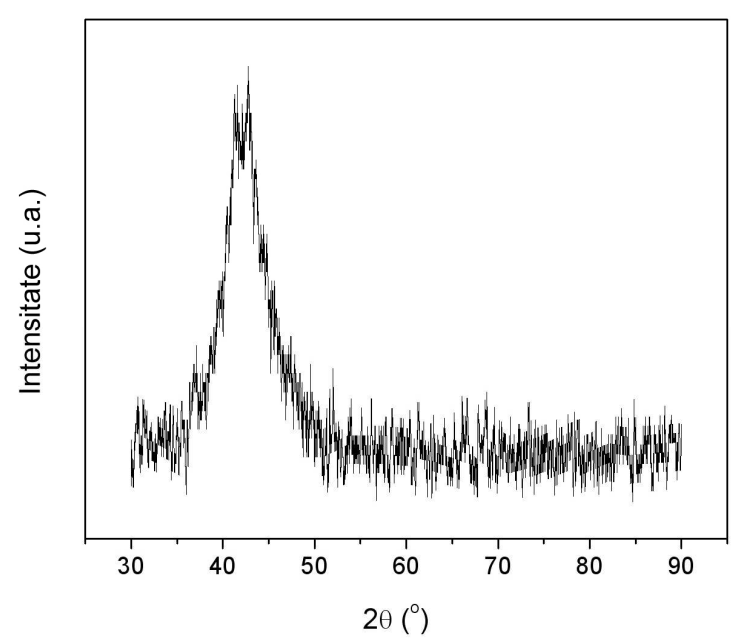

Fig. 1. XRD pattern of the as-quenched Ni40Ti40Nb20 ribbons

Upon heating, the DSC curve exhibits three exothermic reactions having the onset temperatures $\left(\mathrm{T}_{\text {on }}\right)$ at $680 \mathrm{~K}, 828 \mathrm{~K}$ and $960 \mathrm{~K}$ (see Fig. 2). The exothermic reactions correspond to the crystallization of $\mathrm{B} 2-\mathrm{TiNi}$, bcc-Nb solid solution and $\mathrm{Ti}_{2} \mathrm{Ni}$ phases [25].

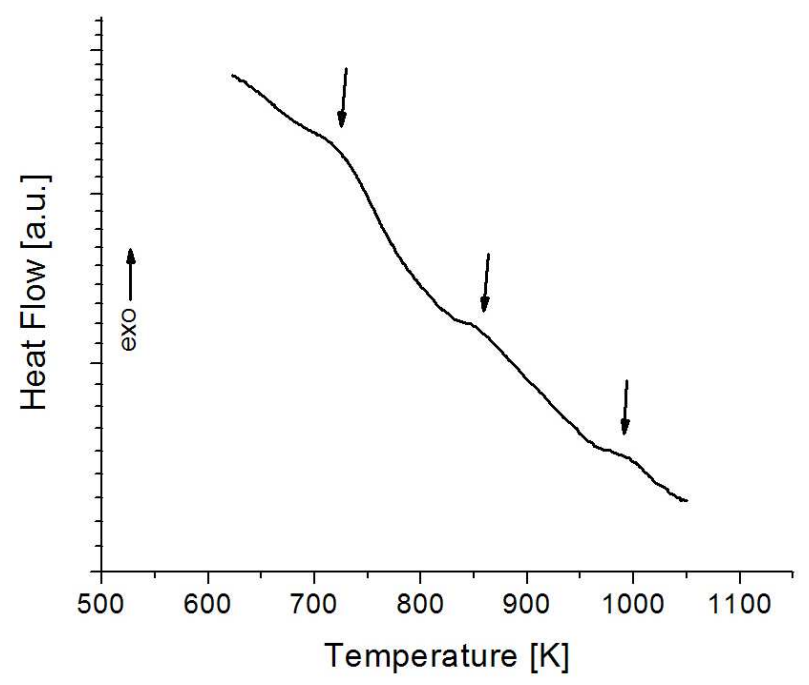

Fig. 2. DSC curve of the as-quenched Ni40Ti40Nb20 ribbons

\section{Corrosion resistance}

Surface analysis such as scanning electron microscopy (SEM) or other instrumental methods (EDX, XRAY, XPS) can be used to evaluate the corrosion resistance of the bipolar plates. Corrosion resistance can also be measured by the amount of ions released from metallic plates into the electrolyte. Electrochemical methods such as potentiodynamic and potentiostatic measurements are the most commonly used methods to observe the corrosion behaviour of metallic bipolar plates.

Most metal corrosion occurs via electrochemical reactions at the interface between the metal and an electrolyte solution. Corrosion normally occurs at a rate determined by equilibrium between the two opposing electrochemical reactions. The first is the anodic reaction, in which a metal is oxidized, releasing electrons into the metal. The other is the cathodic reaction, in which a solution species is reduced, removing electrons from the metal. The potential of the metal is the means by which the anodic and cathodic reactions are kept in balance. This equilibrium potential is called the open circuit potential $\left(\mathrm{E}_{\mathrm{oc}}\right)$. In most electrochemical corrosion experiments, the first step is the measurement of $E_{o c}$. A stable $E_{o c}$ is indicating that the system being studied has reached "steady state", the various corrosion reactions have assumed a constant rate. In Fig. 3.a. the variation of the 
open circuit potential with time is presented. We can see that the $\mathrm{E}_{\mathrm{oc}}$ in the $\mathrm{H}_{2}$-containing environment is higher than that in the case of $\mathrm{O}_{2}$ saturated environment. In both cases the alloy passivates spontaneously.
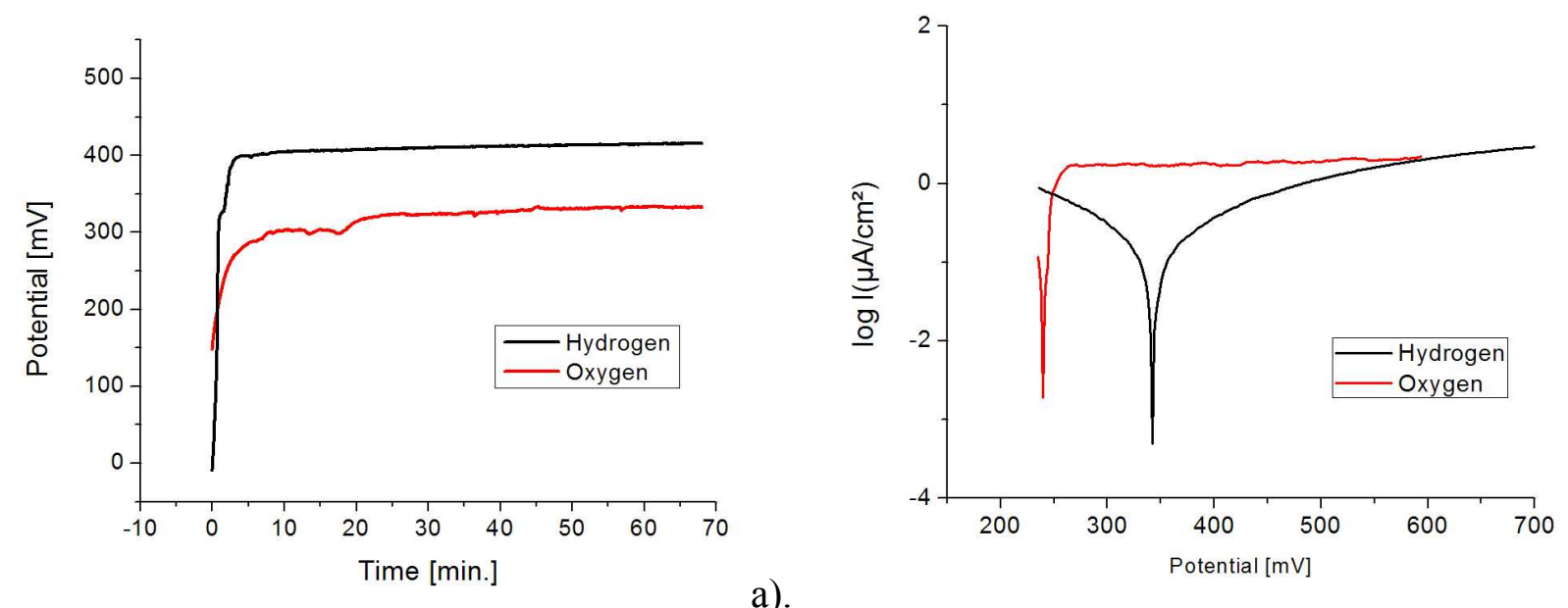

a).

b).

Fig. 3. Open circuit potential (a.) and potentiodynamic curves (b.) at $70^{\circ} \mathrm{C}$ in $1 \mathrm{~N} \mathrm{H}_{2} \mathrm{SO}_{4}$ bubbled with $\mathrm{H}_{2}$ and $\mathrm{O}_{2}$

In a PEM fuel cell, the bipolar plate is subjected to hydrogen rich corrosive environments on one side and oxygen rich on the other. In order to investigate the corrosion characteristics of the $\mathrm{Ni40Ti40Nb20}$ amorphous ribbons in anodic and cathodic conditions, the potentiodynamic tests were done in $\mathrm{H}_{2}$-containing and $\mathrm{O}_{2}$-containing environments, respectively.

Fig. 3.b. presents the potentiodynamic curves in the $\mathrm{H}_{2}$ and $\mathrm{O}_{2}$ environments. Comparing the two curves, we find that the samples corrosion potential in the $1 \mathrm{~N} \mathrm{H}_{2} \mathrm{SO}_{4}$ solution bubbled with $\mathrm{O}_{2}$ is somewhat lower than that in $\mathrm{H}_{2} \mathrm{SO}_{4}$ bubbled with $\mathrm{H}_{2}$, which retards the corrosion of the Ni40Ti40Nb20 amorphous tapes in the $\mathrm{H}_{2}$-containing environment compared with the $\mathrm{O}_{2}$ containing environment. The corrosion current density in $\mathrm{H}_{2} \mathrm{SO}_{4}$ bubbled with $\mathrm{O}_{2}$ is higher than that in $1 \mathrm{~N} \mathrm{H}_{2} \mathrm{SO}_{4}$ bubbled with $\mathrm{H}_{2}$. We can obtain the corrosion parameters in both environments using the linear polarization method; these are presented in table 1.

Table 1. Polarization parameters of the present alloy compared to $316 \mathrm{~L}[26,27]$ at $70^{\circ} \mathrm{C}$

\begin{tabular}{|l|c|c|c|c|c|}
\hline \multicolumn{1}{|c|}{ Sample } & $\begin{array}{c}\mathrm{E}(\mathrm{i}=0) \\
{[\mathrm{mV}]}\end{array}$ & $\begin{array}{c}\mathrm{R}_{\mathrm{p}} \\
{\left[\mathrm{k} \Omega \mathrm{cm}^{2}\right]}\end{array}$ & $\begin{array}{c}\mathrm{i}_{\text {corr }} \\
{\left[\mu \mathrm{A} / \mathrm{cm}^{2}\right]}\end{array}$ & $\begin{array}{c}\mathrm{i}_{\text {anode }} \\
{\left[\mu \mathrm{A} / \mathrm{cm}^{2}\right]}\end{array}$ & $\begin{array}{c}\mathrm{i}_{\text {cathode }} \\
{\left[\mu \mathrm{A} / \mathrm{cm}^{2}\right]}\end{array}$ \\
\hline Ni40Ti40Nb20 in $\mathrm{O}_{2}$ & 243.5 & 41.6 & 1.3 & - & 2 \\
\hline Ni40Ti40Nb20 in $\mathrm{H}_{2}$ & 342.8 & 131.9 & 0.35 & 4.7 & - \\
\hline 316L in $\mathrm{O}_{2}$ & -198 & 5.36 & 2.4 & - & 6 \\
\hline 316L in $\mathrm{H}_{2}$ & -255 & 0.91 & 9.1 & 7 & - \\
\hline
\end{tabular}

The polarization resistance was calculated using the following equation:

$$
R_{p}=\frac{\beta_{a} \beta_{c}}{2.3 i_{c o r r}\left(\beta_{a}+\beta_{c}\right)} \text {. }
$$

where $\beta_{\mathrm{a}}, \beta_{\mathrm{c}}$, are the Tafel slopes of the anodic and cathodic sides, $\mathrm{i}_{\text {corr }}$ the corrosion current density and $R_{p}$ the polarization resistance. Since the polarization resistance is inversely proportional to the rate of corrosion, it can also be used to compare different alloys.

The corrosion current density and the polarization resistance in the $\mathrm{O}_{2}$ environment are $1.3 \mu \mathrm{A} / \mathrm{cm}^{2}$ and $41.6 \mathrm{k} \Omega \mathrm{cm}^{2}$ respectively, as compared to $0.35 \mu \mathrm{A} / \mathrm{cm}^{2}$ and $131.9 \mathrm{k} \Omega \mathrm{cm}^{2}$ in the hydrogen rich environment. The samples have higher polarization resistance and lower corrosion current density in the $\mathrm{H}_{2}$-containing environment, as they passivate more easily in that environment. 
Under approximated operating potentials the alloy behaves well, the corrosion current corresponding to the PEMFC anodic environment ( $-0.1 \mathrm{~V}$ vs the $\mathrm{Ag} \backslash \mathrm{AgCl}$ electrode) is $i_{\text {anode }}=4.7$ $\mu \mathrm{A} / \mathrm{cm}^{2}$ and the corrosion current corresponding to the PEMFC cathodic environment $(+0.6 \mathrm{~V}$ vs the $\mathrm{Ag} \backslash \mathrm{AgCl}$ electrode - segment not presented in Fig. 3.b.) is around $\mathrm{i}_{\text {cathode }}=2 \mu \mathrm{A} / \mathrm{cm}^{2}$. These corrosion currents are significantly lower than those obtained in the case of the $316 \mathrm{~L}$ stainless steel [27].

Further enhancement of the corrosion resistance could be achieved as several studies on aqueous corrosion of glass-forming alloys suggested $[28,29]$ on structurally relaxed metallic glasses.

The improved resistance of amorphous alloys is not only based on their structure itself but also on their ability to promote amorphous oxide formation. Wang [30] explains the good corrosion resistance of the $\mathrm{Ni}-\mathrm{Nb}$ metallic glasses with high $\mathrm{Nb}$ content on the formation of a passive $\mathrm{Nb}_{2} \mathrm{O}_{5}$ oxide layer on the surface. Since most of the metal ion transport into the solution is through grain boundaries and other structural defects, the amorphous nature of the tapes renders the passive film more protective

In the present case, due to a lower $\mathrm{Nb}$ content a preferential dissolution of the $\mathrm{Ni}$ ions from the tapes surface take place [31]. By increasing the local $\mathrm{Nb}$ concentration a passive, $\mathrm{Nb}$ rich film formation is presumed.

Water management inside the fuel cell influences its optimal function. Too much water generated on the cathodic side of the cell can impede the optimal gas flow. Bipolar plates with low surface energy have low water contact angle, and high surface wettability could directly contribute to flooding of cathode side of the fuel cell. To evaluate surface energy of different materials, the water contact angle is measured. High contact angle is an indication of a high surface energy or surface tension of a material and low surface wettability.

Table 2. Comparison of water contact angle for bipolar plate materials

\begin{tabular}{|c|c|c|c|}
\hline Material & Graphite & 316L stainless steel & Ni40Ti40Nb20 \\
\hline Water contact angle $\left[{ }^{\circ}\right]$ & 104 & 74 & 85 \\
\hline
\end{tabular}

\section{Interfacial contact resistance}

The measured total resistance $\left(\mathrm{R}_{\mathrm{T} 1}\right)$ consists of bulk resistance of two current collectors $\left(2 \mathrm{R}_{\mathrm{CC}}\right)$, two interfacial contact resistance (ICR) between current collector (CC) and the gas diffusion layer (GDL) $\left(2 \mathrm{R}_{\mathrm{CC} / \mathrm{GDL}}\right)$, two bulk resistance of GDL $\left(\mathrm{R}_{\mathrm{GDL}}\right)$, two interfacial contact resistance between GDL and bipolar plate (BPP) $\left(\mathrm{R}_{\mathrm{GDL} / \mathrm{BPP}}\right)$, and bulk resistance of the BPP $\left(\mathrm{R}_{\mathrm{BPP}}\right)$. The total resistance can be expressed as follows:

$$
\mathrm{R}_{\mathrm{T} 1}=2 \mathrm{R}_{\mathrm{CC}}+2 \mathrm{R}_{\mathrm{CC} / \mathrm{GDL}}+2 \mathrm{R}_{\mathrm{GDL}}+2 \mathrm{R}_{\mathrm{GDL} / \mathrm{BPP}}+\mathrm{R}_{\mathrm{BPP}}
$$

In order to obtain from the above equation the ICR a calibration measurement is done using a system composed by the gas diffusion layer sandwiched between two current collectors. The obtained resistivity $R_{T 2}$ is equal with

$$
\mathrm{R}_{\mathrm{T} 2}=2 \mathrm{R}_{\mathrm{CC}}+2 \mathrm{R}_{\mathrm{CC} / \mathrm{GDL}}+\mathrm{R}_{\mathrm{GDL}}
$$

In the above relation the bulk resistances of GDL and BPP are negligible $[32,33]$. So the interfacial contact resistance can be calculated by:

$$
\mathrm{R}_{\mathrm{GDL} / \mathrm{BPP}}=\left(\mathrm{R}_{\mathrm{T} 1}-\mathrm{R}_{\mathrm{T} 2}\right) / 2
$$




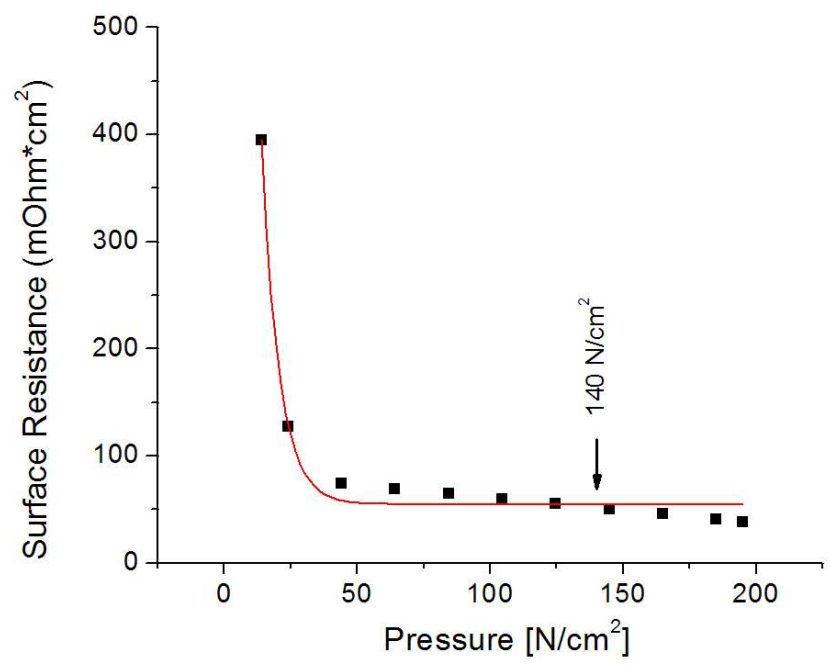

Fig. 5. Interfacial contact resistance of the studied alloy

The decrease of ICR with increasing compaction force is attributed to the increased real contact area at high-compaction forces and is closely related to the mechanical properties of the asperities on the surface.

Table 3. Comparison of the interfacial contact resistance for bipolar plate materials

\begin{tabular}{|l|c|c|c|c|}
\hline Alloy & 316L [34] & Graphite [35] & Ni40Ti40Nb20 & Ni60Nb20Ti10Zr5Ta5 [33] \\
\hline ICR $\left[\mathrm{m} \Omega * \mathrm{~cm}^{2}\right]$ & 50 & 12 & 54 & 19 \\
\hline
\end{tabular}

The variation of the interfacial contact resistance with the applied pressure is presented in Fig. 5. One can compare the ICR of the studied alloy with other BPP materials in the stack assembly condition (an applied pressure of about $140 \mathrm{~N} / \mathrm{cm}^{2}$ ) as presented in table 3 . The interfacial contact resistance is situated between that of the graphite and the $316 \mathrm{~L}$ stainless steel, compared with another Ni-based amorphous alloy it is almost double.

\section{Summary}

We investigated the potential of a metallic glass for the separator of PEMFCs. The results obtained in this study are summarized as follows:

The Ni-based glassy alloy tapes were produced by the single-roller melt-spinning technique. The corrosion rate of the Ni40Ti40 Nb20 glassy alloy in $1 \mathrm{~N}$ sulphuric acid was significantly lower than that of the $316 \mathrm{~L}$ stainless steel.

The higher corrosion resistance could be explained by the effect of niobium in the structure which forms a passive, protecting oxide layer.

The alloy has a high water contact angle which is an indication of a high surface energy and low surface wettability that is needed to prevent the flooding of cathode side of the fuel cell during operation.

The interfacial contact resistance is situated above that of the $316 \mathrm{~L}$ stainless steel.

These findings suggest that the studied alloy has a potential as a separator material; although certain questions remain open like the costs, ease of mass production and if the levels of released metal ion concentration is in the satisfactory limits for optimal PEM fuel cell performance. It is believed that the properties of this amorphous alloy can be further enhanced by an optimization of the alloy composition for PEMFC bipolar plate application. 


\section{Acknowledgements}

This paper was supported by the project "Development and support of multidisciplinary postdoctoral programmes in major technical areas of national strategy of Research - Development Innovation" 4D-POSTDOC, contract no. POSDRU/89/1.5/S/52603, project co-funded by the European Social Fund through Sectorial Operational Programme Human Resources Development 2007-2013.

\section{References}

[1] J. Larminie, A. Dicks, Fuel Cell Systems Explained, second ed., John Wiley \& Sons, West Sussex, 2003.

[2] N.M. Sammes, Fuel Cell Technology, Springer-Verlag, London, 2006

[3] T. Matsuura, M. Kato, M. Hori, Study on metallic bipolar plate for proton exchange membrane fuel cell J. Power Sources. 161 (2006) 74-78.

[4] R.A. Antunes, M.C.L. Oliveira, G. Ett, V. Ett, Carbon materials in composite bipolar plates for polymer electrolyte membrane fuel cells: A review of the main challenges to improve electrical performance, J. Power. Sources. 196 (2011) 2945-2961.

[5] J.W. Lim, M. Kim, K.H. Kim, D.G. Lee, Innovative gasketless carbon composite bipolar plates for PEM fuel cells Int. J. Hydrogen Energy. 37 (2012) 19018-19026.

[6] E. Middelman, W. Kout, B. Vogelaar, J. Lenssen, E. de Waal, Bipolar plates for PEM fuel cells, J. Power. Sources. 118 (2003) 44-46

[7] D.P. Davies, P.L. Adcock, M. Turpin, S.J. Rowen, Bipolar plate materials for solid polymer fuel cells, J. Appl. Electrochem. 30 (2000) 101-105.

[8] S.J. Lee, J.J. Lai, C.H. Huang. Stainless steel bipolar plates. J. Power. Sources. 145 (2005) $362-368$.

[9] J. Wind, R. Spaeh, W. Kaiser, G. Boehm, Metallic bipolar plates for PEM fuel cells. J. Power. Sources., 105 (2002) 256-260.

[10] S. Joseph, J.C. McClure, R. Chianelli, P. Pich, P.J. Sebastian, Conducting polymer-coated stainless steel bipolar plates for proton exchange membrane fuel cells (PEMFC). Int. J. Hydrogen Energy. 30 (2005) 1339-1344.

[11] S.J. Lee, C.H. Huang, Y.P. Chen, C.T. Hsu, PVD coated bipolar plates for PEM fuel cells, J. Fuel Cell Sci. Technol. 2 (2005) 290-294.

[12] Y. Wang, D.O. Northwood, An investigation of the electrochemical properties of PVD TiNcoated SS410 in simulated PEM fuel cell environments, Int. J. Hydrogen Energy 32 (2007) 895-902.

[13] O. Lavigne, C. Alemany-Dumont, B. Normand, S. Berthon-Fabry, R. Metkemeije, Thin chromium nitride PVD coatings on stainless steel for conductive component as bipolar plates of PEM fuel cells: Ex-situ and in-situ performances evaluation, Int. J. Hydrogen Energy 37 (2012) 10789 -10797.

[14] D. Zhang, L. Duan, L. Guo, Z. Wang, J. Zhao, W.-H. Tuan, K. Niihara, TiN-coated titanium as the bipolar plate for PEMFC by multi-arc ion plating, Int. J. Hydrogen Energy, 36 (2011) $9155-9161$.

[15] H. Wang, J.A. Turner, $\mathrm{SnO}_{2}: \mathrm{F}$ coated ferritic stainless steels for PEM fuel cell bipolar plates, J. Power Sources 170 (2007) 387-394.

[16] H. Wang, J.A. Turner, X. Li, R. Bhattacharya, SnO2:F coated austenite stainless steels for PEM fuel cell bipolar plates, J. Power Sources 171 (2007) 567-574.

[17] H. Sun, K. Cooke, G. Eitzinger, P. Hamilton, B. Pollet, Development of PVD coatings for PEMFC metallic bipolar plates, Thin Solid Films 528 (2013) 199-204.

[18] K.S. Weil, G. Xia, Z.G. Yang, J.Y. Kim, Development of a niobium clad PEM fuel cell bipolar plate material, Int. J. Hydrogen Energy 32 (2007) 3724-3733. 
[19] K. Hashimoto, P.Y. Park, J.H. Kim, H. Yoshioka, H. Mitsui, E. Akiyama, H. Habazaki, A. Kawashima, K. Asami, Z. Grzesik, S. Mrowec, Recent progress in corrosion resistant metastable alloys, Mater. Sci. Eng. A, 198 (1995) 1-10.

[20] S. Jayalakshmi, V.S. Vasantha, E. Fleury, M. Gupta, Characteristics of Ni-Nb-based metallic amorphous alloys for hydrogen-related energy applications, Appl. Energ. 90 (2012) 94-99

[21] A. Inoue, T. Shimizu, S. Yamaura, Y. Fujita, S. Takagi, H.M. Kimura, Development of glassy alloy separators for a proton exchange membrane fuel cell (PEMFC), Mater. Trans. 46 (2005) $1706-1710$.

[22] H. Yoshioka, K. Asami, A. Kawashima, K. Hashimoto. Laser processed corrosion-resistant amorphous Ni-Cr-P-B surface alloys on a mild steel,. Corros. Sci. 27 (1987) 981-995.

[23] M. Yokoyama, S. Yamaura, H.M. Kimura, A. Inoue. Viscous flow workability of Ni-Cr-P-B metallic glasses produced by meltspinning in air, Mater. Trans. 48 (2007) 3176-3180.

[24] H. Wang, M.A. Sweikart, J.A.Turner, Stainless steel as bipolar plate material for polymer electrolyte membrane fuel cells. J Power Sources 115 (2003) 243-251.

[25] M. Nishida, M. Matsuda, Y. Shimada, K. Takashima, K. Ishikawa, K. Aoki, Microstructural and Mechanical Characterizations of Rapidly Solidified Nb-TiNi Hydrogen Permeation Alloy J. Phys. Conf. Ser. 144 (2009) 012106.

[26] Y. Wang, D.O. Northwood, Effects of $\mathrm{O}_{2}$ and $\mathrm{H}_{2}$ on the corrosion of SS316L metallic bipolar plate materials in simulated anode and cathode environments of PEM fuel cells Electrochim. Acta. 52 (2007) 6793-6798.

[27] E. Dura, Ö. N. Cora, M. Koc, Effect of manufacturing conditions on the corrosion resistance behavior of metallic bipolar plates in proton exchange membrane fuel cells, J.Power. Sources. 196 (2011) 1235-1241

[28] H.X. Li, S.Yi, Corrosion behaviors of bulk metallic glasses $\mathrm{Fe}_{66.7} \mathrm{C}_{7.0} \mathrm{Si}_{3.3} \mathrm{~B}_{5.5} \mathrm{P}_{8.7} \mathrm{Cr}_{2.3} \mathrm{Al}_{2.0} \mathrm{Mo}_{4.5}$ having different crystal volume fractions, Mater. Chem. Phys. 112 (2008) 305-309.

[29] W.H. Jiang, F. Jiang, B.A. Green, F.X. Liu, P.K. Liaw, Electrochemical corrosion behaviour of a Zr-based bulk-metallic glass, Appl. Phys. Lett. 91 (2007) 041904

[30] Z.M. Wang, J. Zhang, X.C. Chang, W.L. Hou, J.Q. Wang, Structure inhibited pit initiation in a $\mathrm{Ni}-\mathrm{Nb}$ metallic glass, Corros. Sci. 52 (2010) 1342-1350.

[31] NC Grant, MD Archer. The electrochemistry of glassy $60 \mathrm{Ni}-40 \mathrm{Nb}$ in aqueous media, J Electrochem. Soc. 131 (1984) 997-1003.

[32] J. Andre, L. Antoni, J. Petit, E. De Vito, A. Montani, Electrical contact resistance between stainless steel bipolar plate and carbon felt in PEFC: a comprehensive study, Int. J. Hydrogen Energy 34 (2009) 3125-3133.

[33] J. Jayaraj, Y.C. Kim, H.K. Seok, K.B. Kim, E. Fleury, Development of metallic glasses for bipolar plate application. Mater, Sci, Eng, A. 449-451 (2007) 30-33.

[34] D.P. Davies , P.L. Adcock, M. Turpin, S.J. Rowen, Stainless steel as a bipolar plate material for solid polymer fuel cells J. Power Sources 86 (2000) 237-242.

[35] W. Yoon, X. Huang, P. Fazzino, K.L. Reifsnider, M.A. Akkaoui, Evaluation of coated metallic bipolar plates for polymer electrolyte membrane fuel cells J. Power Sources 179 (2008) 265-273. 